\title{
Uranium Deposits in
}

\section{Oolitic Limestone Near}

\section{Mayoworth, Johnson}

County, Wyoming

GEOLOGICAL SURVEY BULLETIN 1030-K

This report concerns work done on behalf of the U.S. Atomic Energy Commission and is published with the permission of the Commission. 


\section{Uranium Deposits in}

Oolitic Limestone Near

Mayoworth, Johnson

County, Wyoming

By R. R. GUILINGER and P. K. THEOBALD

CONTRIBUTIONS TO THE GEOLOGY OF URANIUM

GE O L O I C A L S U R V E Y B U L L E T I N 1030-K

This report concerns work done on behalf of the U. S. Atomic Energy Commission and is published with the permission of the Commission.

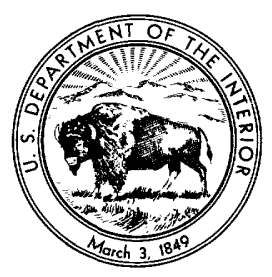




\title{
UNITED STATES DEPARTMENT OF THE INTERIOR
}

\author{
Fred A. Seaton, Secretary
}

GEOLOGIGAL SURVEY

Thomas B. Nolan, Director 


\section{CONTENTS}

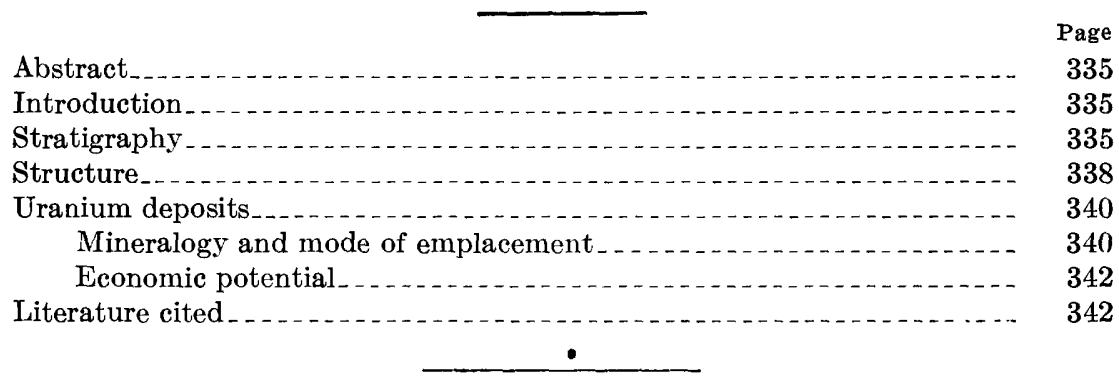

\section{ILLUSTRATIONS}

FIGURE 62. Map showing distribution of radioactive localities in the Sundance formation near Mayoworth......................

63. Photomicrograph of limestone showing radial and concentric

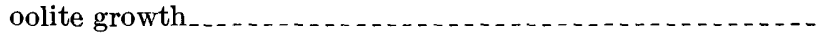

64. Photomicrograph of limestone showing a metatyuyamunitefilled fracture.

65. Map showing lithologic units and structure of part of the Sundance formation near Mayoworth

66. Photomicrograph of limestone showing opaque uranium(?) mineral veining an oolite 

CONTRIBUTIONS TO THE GEOLOGY OF URANIUM

\title{
URANIUM DEPOSITS IN OOLITIC LIMESTONE NEAR MAYOWORTH, JOHNSON COUNTY, WYOMING
}

\author{
By R. R. Guilinger and P. K. Theobald
}

\begin{abstract}
The uranium deposits of the Mayoworth area, Johnson County, Wyo., are in oolitic limestone at the base of the Sundance formation of Late Jurassic age. The uranium mineral has been identified as metatyuyamunite, a hydrous calcium uranium vanadate that coats joints and fractures and replaces calcite in both the cement and the oolites. In the largest area of measured radioactivity, the deposits are coatings on joint surfaces, but in the other areas, replacement of oolites and cement is most common. Some of the uranium may be syngenetic. Secondary metatyuyamunite has been concentrated along groundwater channels. The uranium content ranges from 0.017 to 0.32 percent and the $\mathrm{V}_{2} \mathrm{O}_{5}$ content ranges from 0.06 to 0.17 percent. The known deposits of the area are of sub-ore grade and are not of economic importance at this time.
\end{abstract}

\section{INTRODUCTION}

The uranium deposits of the Mayoworth area are 2.2 miles south of the abandoned postoffice at Mayoworth, Johnson County, Wyo. The area is accessible by a dirt road from Mayoworth, which is reached by a paved secondary road from U. S. Highway 87 at Kaycee.

The stratigraphy and structure of the area surrounding the uranium deposits have been mapped and described by Richardson ${ }^{\mathrm{I}}$ and the general area to the north by Hose (1954). Love (1954) described the uranium deposits of the Mayoworth area.

To evaluate the economic potential and to study controls of deposition of the uranium, the writers examined the deposits in August 1954 and mapped the area by plane table methods in September 1954 . This work was done by the U. S. Geological Survey on behalf of the Division of Raw Materials of the U. S. Atomic Energy Commission.

\section{STRATIGRAPHY}

Sedimentary rocks of Triassic and Jurassic age are exposed in the immediate vicinity of the Mayoworth uranium deposits. The Chugwater formation of Triassic age is composed of massive red sandstones

\footnotetext{
1 Richardson, A. L., 1950, Geology of the Mayoworth region, Johnson County, Wyoming: Univ, of Wyoming, M. A. thesis, unpub.
} 
and shales. The Sundance formation of Late Jurassic age unconformably overlies the Chugwater formation. In the mapped area (fig. 1), the Sundance formation is divided into three units. The basal unit, in which the uranium deposits occur, is a gray oolitic

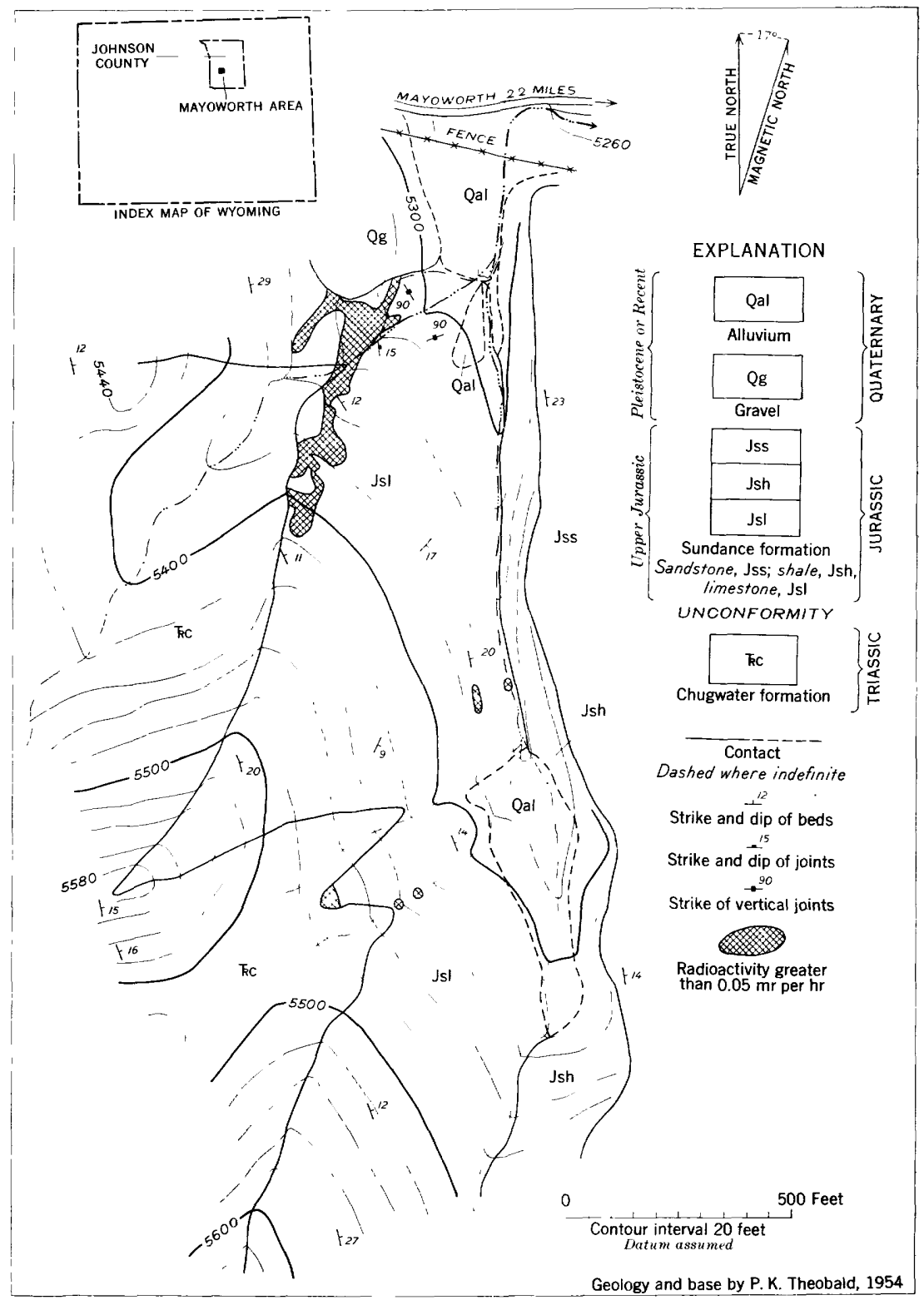

FIGURE 62.-Map showing distribution of radioactive localities in the Sundance formation near Mayoworth, Johnson County, Wyo. 
limestone, 8 to 10 feet thick. Conformably overlying the limestone is 30 feet of soft gray fossiliferous shale, and directly overlying the shale is white to buff sandstone. Isolated patches of gravel of late Cenozoic age uncomformably overlie both the Triassic and Jurassic rocks.

The limestone of the Sundance formation is composed of oolites formed primarily around elongate cores of colorless calcite. The oolites are generally uniform in size, averaging about $0.5 \mathrm{~mm}$ in diameter but ranging from $0.1 \mathrm{~mm}$ to $2 \mathrm{~mm}$ in diameter. They tend to follow the form of the cores, with elongated shapes predominant. Radial and concentric growth is evident around the cores, and in many oolites both kinds occur (fig. 63). Where both forms of growth

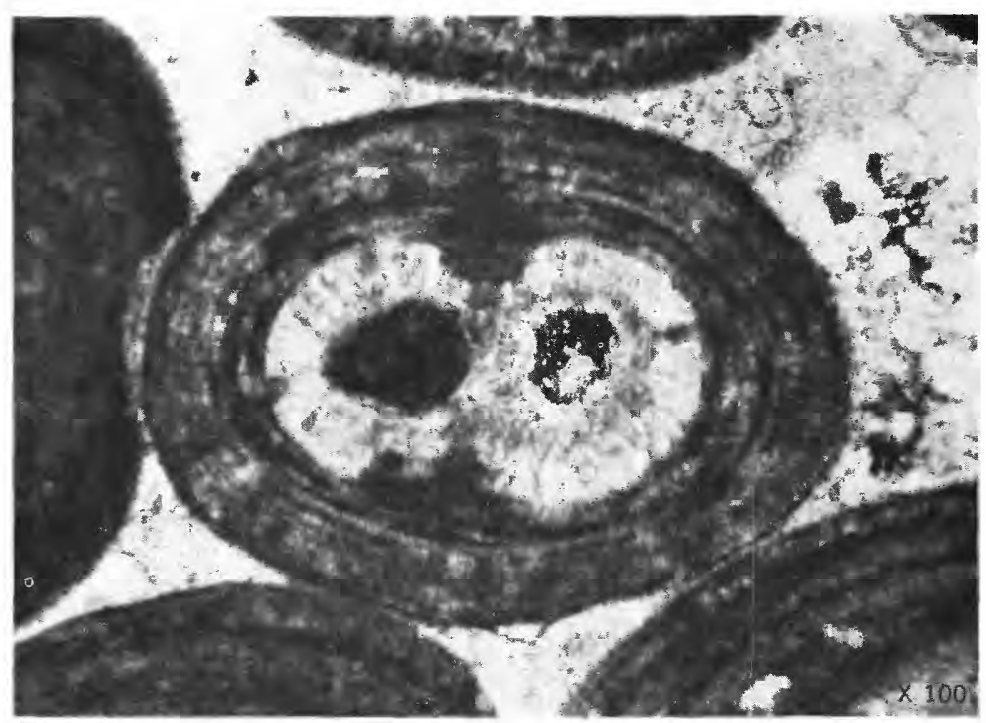

FIGCRE 63.-Photomicrograph of limestone near Mayoworth, Wyo., showing radial and concentric oolite growth. Crossed nicols. $\times 100$.

are present in a single oolite, the radial growth is on the inside, surrounded by the concentric rings and separated from the concentric rings by a thin layer of clay. This suggests two stages and two processes of oolite formation with a slight interruption between the stages. Another interruption in the oolite formation is suggested by some corrosion and clay accumulation on a concentric ring at about the same position in several oolites.

Though most of the cores consist of colorless calcite, there are other kinds. Of these, fossils are the most common. They include small pelecypod shells, Foraminifera(?), or shell fragments. Opaque black minerals form the cores of some oolites. Most of these black minerals are hematite or goethite, but some have not been positively identified. The cores of some oolites are quartz grains, but grains of this mineral 
are generally larger and occur as clastic grains free of oolite forming calcite.

The oolites are imbedded in a cement of colorless coarsely crystalline calcite. At the time of cementation some solution of the oolites occurred, and their outer edges appear corroded and partly replaced by the cementing calcite. Later solutions, apparently moving along the interfaces between the cement and the oolites, introduced iron oxide that replaced both the cement and oolites. In some places the cement is completely replaced by iron oxide, and an unidentified green mineral replaces the edges of some oolites. In places finely divided iron oxide gives a reddish color to the oolites and cement. Hematite and metatyuramunite have filled fractures that cut both the cement and oolites (fig. 64).

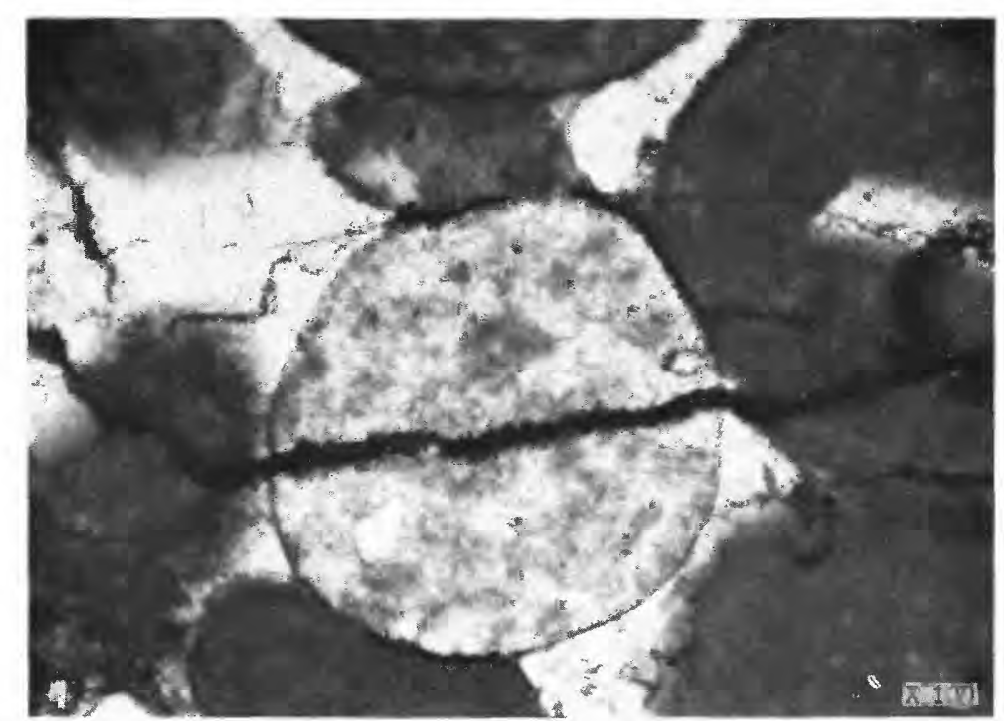

FIGURE 64.-Photomicrograph of limestone near Mayoworth, Wyo., showing a metatyuyamunite-filled fracture. $\times 100$.

\section{STRUCTURE}

The Mayoworth area is on the southeast flank of the Bighorn arch. The sedimentary rocks in the Mayoworth area are separated from Precambrian crystalline rocks to the north by a northwest-trending thrust fault about 6 miles north of the mapped area. South of this thrust fault, the east limb of the major arch is warped into smaller anticlines and synclines. The uranium-bearing limestone is exposed on the east limb of an anticline that forms the eastern limit of exposure of the minor folds.

The structure in the vicinity of the uranium occurrences is shown on figure 65. The strike of the Chugwater formation and the sandstone of the Sundance formation is uniform. The Chugwater forma- 


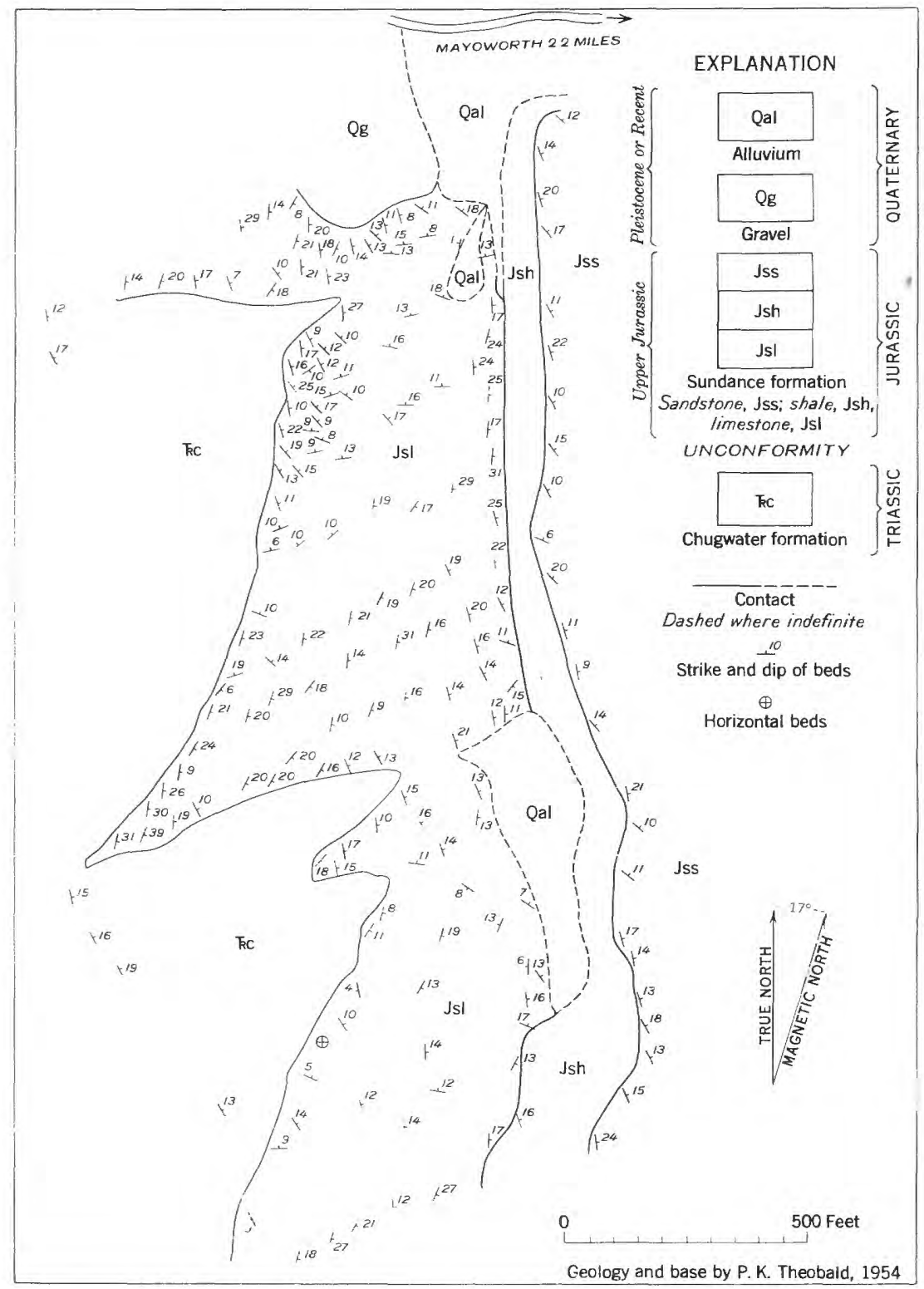

Figcre 65.-Map showing lithclogic units and structure of part of the Sundance formation near Mayoworth, Johnson County. Wyo.

tion has an average strike of $\mathrm{N} .23^{\circ} \mathrm{W}$., and an average dip of $15^{\circ}$ NE. ; the sandstone unit of the Sundance formation has an average strike of N. $28^{\circ} \mathrm{W}$., and an average dip of $14^{\circ} \mathrm{NE}$. The structure of the oolitic limestone is complex; bedding planes are warped, and there is some crossbedding. The erratic strike and dip symbols on figure 63 reflect these features. 
Three sets of joints are conspicuous in the limestone; one is essentially parallel to bedding and strikes from N. 15 to $20^{\circ} \mathrm{W}$., and two are vertical with strikes of N. $70^{\circ} \mathrm{E}$. and N. $30^{\circ} \mathrm{W}$. (fig. 62). The joints probably were formed during the Laramide orogeny. No faults were observed in the area mapped.

\section{URANIUM DEPOSITS}

\section{MINERALOGY AND MODE OF EMPLACEMENT}

Metatyuyamunite, a hydrous calcium uranium vanadate, was identified by W. F. Outerbridge of the Geological Survey by X-ray methods in a selected sample of oolitic limestone. It occurs as coatings on joints and small fractures and as replacements of calcite in the cement and oolites. In zones of highest radioactivity, metatyuyamunite is prominent as joint coatings, particularly in the north half of the mapped area. The coatings are most conspicuous along joints striking $\mathrm{N} .70^{\circ} \mathrm{E}$. and N. $15^{\circ} \mathrm{W}$.

In the less radioactive rocks, replacement was the most common mode of emplacement. Uranium-bearing solutions entered the limestone along small fractures, and replaced cement or oolites adjacent to the fractures. Where fractures are absent the solutions appear to have moved along the interfaces between crystals of the cement or more commonly between cement and oolites. In the latter, both cement- and oolite-forming calcite were replaced, but the ooliteforming calcite seems to be more susceptible to replacement. In several thin sections only the oolites or oolite cores were replaced but there is no evidence of channels through which replacing solutions could have entered. In one polished section an unidentified black mineral formed the core of the oolite. This black mineral has a dark-gray or black streak in contrast to the red and brown streak of the iron minerals. Immediately surrounding this black mineral is an orange alteration product, which is surrounded in turn by a concentration of a yellow uranium mineral. The black mineral may be a syngenetic primary uranium mineral, but it is too small to be positively identified. An autoradiograph of this polished section gave inconclusive results. The same polished section also showed a black mineral, with orange and yellow alteration halos, veining an oolite (fig. 66).

Association of the radioactive rocks with present water courses is evident from figure 62, suggesting some geomorphic control of the deposits. The relations of the Quaternary gravel shown at the north end of the map and similar occurrences at about the same altitude north of the mapped area suggest that the present trunk stream, which parallels the road shown at the north edge of figure 62, developed its course after the gravel was deposited. The small streams shown 


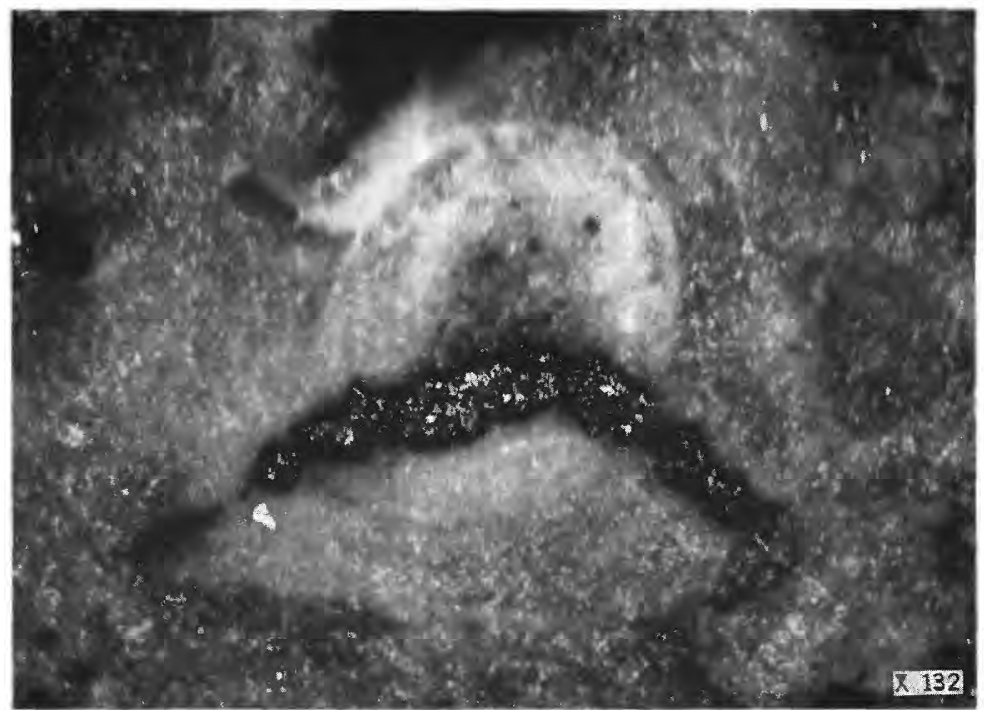

Figure 66.-Photomicrograph of limestone near Mayoworth showing opaque uranium(?) mineral veining an oolite. $\times 132$.

on figure 62 are entrenched along their lower reaches. Along most of the stream that flows parallel to the strike along the contact of the limestone and shale there is no flood plain though there is a welldeveloped flood plain near its head in the south half of the map.

Anomalous radioactivity is confined to areas as high or higher than the Quaternary gravel and the patch of alluvium at the head of the strike valley. This suggests that at least some of the uranium concentration took place along the courses of mature streams as they entered the limestone at the two gaps in the flatirons shown on the west side of figure 62. Channels of flow would be northeast along the bedding-plane joints and the vertical joints parallel to the stream flow, and not along vertical northwest-striking joints perpendicular to the flow. Thus greater uranium concentrations should occur along the joints striking $\mathrm{N} .70^{\circ} \mathrm{E}$. and $\mathrm{N} .15^{\circ} \mathrm{W}$., as they do.

In the discussion of the uranium mineralogy it is suggested that some of the uranium minerals may be syngenetic. If this is true, syngenetic uranium could have been leached from the limestone up dip and reconcentrated as secondary metatyuyamunite along ground water channels such as joints and fractures in the limestone. Love (1954) suggests that solutions bearing uranium could have been derived from tuffaceous rock in the White River formation of Oligocene age, which may have covered this area. Also, streams entering the Mayoworth area could have derived uranium from known bodies of radioactive rocks higher in the Bighorn Mountains (Hose, 1954, and Jones, 1952). 


\section{ECONOMIC PO'TENTIAL}

About 20,000 square feet within the area mapped is more radioactive than 0.05 milliroentgens per hour $(\mathrm{mr}$ per $\mathrm{hr}$ ). Maximum radioactivity is 2 mrperhr in the large mineralized zone in the north balf of the area (fig. 62) where the background is 0.1 mrperhr. There are several areas of high radioactivity in the south half of the mapped area where a maximum radioactivity of $0.25 \mathrm{mrperh}$ was noted. The average background for the southern area is $0.025 \mathrm{mrperhr}$. Radioactive localities also occur in the limestone north and south of the area mapped.

Analyses of samples from the Mayoworth deposits indicate that the radioactivity ranges from 0.04 to 0.16 percent equivalent uranium (see table below). The uranium content ranges from 0.017 to 0.32 percent. The $\mathrm{V}_{2} \mathrm{O}_{5}$ content ranges from 0.06 to 0.17 percent. The $\mathrm{CaCO}_{3}$ content of sample 214833 is 96.3 percent.

Analyses of samples from the Mayoworth area

\begin{tabular}{|c|c|c|c|c|c|}
\hline $\begin{array}{l}\text { Laboratory } \\
\text { sample No. }\end{array}$ & $\begin{array}{c}\mathrm{eU} \\
\text { (percent) }\end{array}$ & $\stackrel{\mathrm{U}}{\text { (percent) }}$ & $\begin{array}{c}\mathrm{V}_{2} \mathrm{O}_{5} \\
\text { (percent) }\end{array}$ & Description of sample & Location \\
\hline D-97107 1 & 0.16 & 0.21 & 0.17 & $\begin{array}{l}\text { Selected sample of } \\
\text { oolitic lime- } \\
\text { stone. }\end{array}$ & $\begin{array}{l}\text { Radioactive de- } \\
\text { posit } 500 \text { feet } \\
\text { south of road. }\end{array}$ \\
\hline D-97108 ${ }^{1}$ & .039 & .052 & .06 & $\begin{array}{l}\text { Grab sample of } \\
\text { oolitic lime- } \\
\text { stone. }\end{array}$ & Do. \\
\hline $\mathrm{RW}-5132^{2}$ & $\ldots$ & .32 & & $\begin{array}{l}\text { Selected sample of } \\
\text { oolitic lime- } \\
\text { stone. }\end{array}$ & Do. \\
\hline $214833^{1}$ & .040 & .017 & .10 & $\begin{array}{l}\text { Grab sample of } \\
\text { oolitic lime- } \\
\text { stone. }\end{array}$ & $\begin{array}{l}1 / 2 \text { mile south of } \\
\text { mapped area. }\end{array}$ \\
\hline
\end{tabular}

1 Analysts: S. Furman, W. Mountjoy, J. Wilson, H. Lipp, J. Schuch, U. S. Geological Survey.
Analyst: J. J. Warr, U. S. Geological Survey.

The known uranium deposits of the Mayoworth area are of sub-ore grade, and of small size. Vanadium content of the deposits is too small to provide a by-product. From the available information it is unlikely that large, high-grade deposits occur in the oolitic limestone.

\section{LTTERATURE CITED}

Hose, R. K., 1954, Geology of the Crazy Woman Creek area, Johnson County, Wyo.: U. S. Geol. Survey Oil and Gas Map OM 142.

Jones, E. E., 1952, Airborne radiometric survey of the east flank of the Big Horn Mountains, Wyoming and Montana: U. S. Atomic Energy Commission RME-4006, Tech. Inf. Service, Oak Ridge, Tenn.

Love, J. D., 1954, Uranium in the Mayoworth area, Johnson County, Wyo.-A preliminary report: U. S. Geol. Survey Circ. 358 . 